\title{
Private Label Distribution
}

National Cancer Institute

\section{Source}

National Cancer Institute. Private Label Distribution. NCI Thesaurus. Code C73608.

An item or service produced by one company for distribution under another company's name. 